\title{
THE POLITICAL IDENTITY OF ULAMA IN THE 2014 INDONESIAN PRESIDENTIAL ELECTION
}

\section{Leni Winarni}

Sebelas Maret State University, Surakarta, Indonesia

email:leniwinarni@gmail.com

\section{Abstract}

The Indonesian presidential election of 2014 was possibly the most exciting, lively, intriguing, emotional, and brutish in the history of presidential elections since reformation in 1998. This paper explores the relationship between the political identities of ulama and their political views in the 2014 Indonesian presidential election. It argues that their political endorsement of presidential candidates is not based on interest but on their political identity. By using constructivist ideas about identity, ulama's political identities are constantly changing and influenced by factors beyond identity. This idea also emphasizes that identity is created and subjective. Transformation of the political identities of ulama is a way of showing their existence in the period since Indonesian independence in 1945. This paper explores how the political identities expressed by ulama infuenced voters in the recent presidential election. How did their political identity affect both the kinds of political measures they took and their support for one of the president candidates? Did the ulama play a substantial political role in election of President Joko Widodo, or were there other factors? Is their political identity the salient factor in their support for either Prabowo Subianto or Joko Widodo?

[Pemilu presiden tahun 2014 memang sangat menarik, hidup, penub emosi, babkan penub intrik, jika dibandingkan dengan sebelumnya sejak. 1998. Paper ini meneliti bubungan politik identitas yang dibawa oleh ulama dan pandangan politiknya pada pemiliban presiden Indonesia tabun 2014. Paper ini menemukan babwa pandangan mereka tentang calon presiden tidak sertamerta menyangkut kepentingan politik, tetapi lebih pada politik. 
Leni Winarni

identitas. Politik identitas para ulama terus berubah dan dipengarubi oleb banyak hal di luar identitas tersebut. Ini juga menegaskan babwa identitas itu ciptaan dan sekaligus subjektif. Transformasi politik identitas para ulama merupakan cara mereka menampakkan keberadaannya, babkan sejak masa kemerdekaan 1945. Paper ini meneliti politik identitas yang ditampake.kn para ulama yang mempengarubi para pemilib dalam pemilu presiden. Bagaimana politik identitas itu berpengarub pada politik dan piliban serta dukungan presiden? Apakah ulama memainkan sesuatu dalam proses terpilibnya Presiden Joko Widodo, atan adakah faktor lain? Apakah hanya identitas yang menjadi satu-satunya faktor untuk mendukung Prabowo Subianto atau Joko Widodo?]

Keywords: ulama, political identity, Indonesian presidential election.

\section{A. Introduction}

Despite involvement of ulama in Indonesian elections since the first election in 1955, in 2014 ulama played a more significant role in the victory of Widodo. The recent House of Representatives election was disappointing since not a single Islamic party was able to reach the $25 \%$ required to nominate a presidential candidate. They were driven to construct a coalition and look for other support out of political circumstance, among, for instance, ulama.

During the campaign of early June-July 2014, the ulama declared their views distinctly. This was a phenomenon in election history in which the public could not only give their own perspective, but also perpetually expressed provocation, contempt, harassment, and defamation in particular social media. Hence, the ulama used a fatwa to attempt to gain the attention of voters and alter their votes.

Several pertinent questions arise in relation to the transformation of the political identities of ulama during the presidential election in 2014. To address them, this paper will (1) describe the roles of the ulama in presidential elections since 2004, in the period following the end of the authoritarian regime in 1998; (2) analyze the transformation of their political identities by using a constructivist perspective seen from the dynamics of their performances and gestures; (3) explain the changes in the political identities of ulama as determining their political interest in supporting either Joko Widodo or Prabowo Subianto; (4) provide a map of those ulama who supported both presidential candidates; (5) explore 
the main factors which influenced the changes in the political identity of ulama; and (6) examine the behavior of the ulama during the campaign. This exposition provides several hypotheses and argues that ulama have created their own political identity based on the notion of constructivism together with evaluation of the election result, the media, and literature about the political involvement of ulama in Indonesia. Meanwhile their political identities continue to change. These changes will motivate their political interests in the next Indonesian presidential election.

\section{B. The Role of Ulama in the Presidential Elections, 2004 to 2014}

In the first six years after the fall of Soeharto and in the lead up to the first direct election of both the House of Representatives and the President in 2004, Indonesia went through a period of democracy. In fact in the period of early independence as young nation, the state adopted a liberal democracy model and multiparty system. ${ }^{1}$ Democracy in Indonesia has a complicated history and the term democracy has been used to legitimize authoritarianism. When Soekarno was replaced, Soeharto established Pancasila as asas tunggal (the sole principal) which encompassed all Indonesian political life. ${ }^{2}$ Significantly, the Islamist parties had merged into the Party for the Development of Indonesia (Partai Persatuan Pembangunan; PPP) and lost many of their voters from among the traditional muslim community.

In 1999, 20 Islamic parties contested the House of Representatives election from a total of 48 parties that were able to pass the requirements. But a special parliamentary session in October 1999 delivered the presidency to Wahid and the vice presidency to Megawati, even though Megawati's PDIP dramatically outperformed Wahid's PKB party in the June ballot. ${ }^{3}$

In 2004, the first direct Indonesian presidential election candidates included several politicians, retired army generals, businessman, and ulama. Five candidate pairs competed to win the 5 July election. The new democratic tradition had just begun in the multi nation-state; meanwhile the state had an enhanced amount of political and economic agendas during the transition.

1 Anies Rasyid Baswedan, "Political Islam in Indonesia: Present and Future Trajectory”, Asian Survey, Vol. 44, No. 5 (2004), pp. 669-690.

${ }^{2}$ Ibid., p. 671.

3 Dan Slater, "The Ironies of Instability in Indonesia", Social Analysis, vol. 50, no. 1 (2006), p. 210. 
Two vice presidential candidates derived from Nadhatul Ulama (NU), the largest muslim organization in Indonesia. This means that Wiranto and Megawati chose NU leaders as their running mates based on the old paradigm of elections, which assumed that leaders of mass organizations could count on support based on traditional loyalties. ${ }^{4}$ Furthermore, Salahuddin Wahid and Hasyim Muzadi were not only NU political leaders, both were also charismatic and popular ulama, in particular among NU loyalists. Nevertheless, did ulama provide support to the two NU presidential candidates? And if Muhammadiyah had backed Amien Rais would he have become the next president?

The political identities of ulama were being examined and became more complicated in terms of why they supported candidates and whether the candidates supported derived from among ulama or Islamist organizations. The NU ulama would have logically chosen candidates from NU, but on the contrary they didn't. In the politics safari opportunities, Hamzah Haz also received support from NU. ${ }^{5}$ Whereas NU didn't declare support for the candidates, Muhammadiyah undeniably supported Amien Rais to contest the presidential election.

The second Indonesian presidential election in 2009 was contested by 3 candidate pairs, but none derived from Islamic parties and Islamic organizations causing a declining in their percentage result in the parliamentary election. The National Awakening Party (Partai Kebangkitan Bangsa; PKB)-affiliated with NU, lost almost half of its votes compared to the election in $2004 .{ }^{6}$ This indicates that the politics of aliran (a term for Islamist parties) evidently failed to convince followers to support their own candidates. ${ }^{\text {? }}$

Meanwhile, in his political context, in order to obtain the support of ulama, Jusuf Kalla was said by the leader of NU boarding school in Magelang to be a representive of NU even though he was never really

4 The Carter Center 2004 Indonesia Election Report (Atlanta: The Carter Carter, 2005), p. 51, https://www.cartercenter.org/documents/2161.pdf, accessed 11 May 2014.

5 Umi Kalsum, “200 Kiai-Habib Dukung Hamzah”, detikNews, http:// news.detik.com/read/2004/05/29/164350/159079/10/200-kiai-habib-dukunghamzah?n992204fksberita, accessed 20 Sep 2014.

6 PKB's share of the vote in legislative elections in this region declined from $36 \%$ in 1999 to $31 \%$ in 2004 and only 12\% in 2009; Ignatius Kristanto, "Tembok Pembatas Mulai Terbelah", Kompas (22 Jun 2009), p. 8.

7 Aurel Croissant and Beate Martín, Between Consolidation and Crisis: Elections and Democracy in Five Nations in Southeast Asia (Leiden: Royal Netherlands Institute of Southeast Asian and Caribbean Studies, 2006), p. 140. 
actively involved in that organization but was rather a Golkar Party (Partai Golongan Karya) politician. ${ }^{8}$ This statement seemed to authorize that Jusuf Kalla was given the blessing of the NU ulama in the 2009 presidential election. Ulama have rarely associated Golkar with Islam and most observers classify Golkar as a nationalist, secular, and pluralistic party, similar to the PDIP. ${ }^{9}$ In fact, Susilo Bambang Yudhoyono (SBY) won majority votes with more than 60\% in 2009 presidential election.

Asking for support from the ulama during presidential election campaigns became a tradition in Indonesian political culture where nearly 90 percent of the population are Muslim. All in all, there are several conclusions that can be used as a reference in describing the role of ulama. First, ulama in Indonesian society are seen as Muslim leaders. They are considered capable of influencing people's choices during presidential election campaigns. Second, the assessment of ulama in relation to candidates has effected public opinion. In Indonesia, the leader is ordinarily assumed to be a perfect person from the Muslim perspective. Finally, the candidates not authorized by the ulama can be assumed to be rejected as Muslim leaders.

\section{The Political Identities of the Ulama}

Muslim groups played an important role in the fall of Soeharto, ending a long period of autocratic rule, therefore providing an impetus for the growth of democracy, but the rise of political Islam has also worried some, for it could be incompatible with democracy. ${ }^{10}$ The increase in the Islamic radicalism movement might become the greatest challenge to democracy. Additionally, the international system has been constructing Islam as a global interest after Cold War. While the process of democratization is difficult in Muslim countries, Indonesia presents a mixed picture.

During Reform Era, Indonesia has experienced three direct presidential elections. The Islamic parties as symbols of political Islam transformed in popularity and support for them declined. On the other hand, in every presidential election, candidates of all parties seek the

8 “JK-Win Minta Dukungan Warga Ponpes di Magelang”, Kompas.com (19 May 2009), http://lipsus.kompas.com/grammyawards/read/2009/05/19/19313579/ JK.Win.Minta.Dukungan.Warga.Ponpes.di.Magelangjk2009, accessed 5 Nov 2014.

9 Baswedan, "Political Islam in Indonesia", p. 674.

10 Azyumardi Azra, Indonesia, Islam, and Democracy: Dynamics in a Global Context (Jakarta: Solstice Publishing, 2006), p. 5. 
blessing of the ulama. The ulama then provide the normative symbols message. The language which understood in vary interpretation by their followers.

Ulama as a part of political Islam, are also in the process of transforming and changing their political identity. Political identity in the constructivist perspective is something that is deliberately created and ontologically is idealistic rather than materialist. Constructivists argue that material structures acquire social significance only via the intersubjectivity of shared meaning structures through which they are mediated. ${ }^{11}$ Constructivists do not deny the phenomenal reality of material processes, but they suggest that one can only understand actors' behavioral responses to said phenomena by reference to the shared meaning structures through which these processes are perceived and understood. ${ }^{12}$ Accordingly, the political identities of ulama are socially constructed. Although Prabowo Subianto is rumored to be an ambitious person prone to dictatorial tendencies in running a government and therefore seen as a potential threat to the ideal of democracy, how the ulama see him depends on their circumstances, interests and political identities.

Second, constructivists posit a mutually constitutive relationship between agents and structures. ${ }^{13}$ Individual agents are the ultimate source of the rules that constitute a social order; individuals make and alter structural reality. ${ }^{14}$ Agency is the perceived ability to purposefully change some part of social or material reality in a creative way. Political identity transformation can be analyzed by finding out about the causes of the behavior change. The interest of actors is not fixed but malleable and ever changing. While constructivists, like other theories, differ among themselves, they share the common understanding that discourse shapes how political actors define interest and thus modify their behavior. At the same time, social arrangements argue the question of who am I, as both logically and ontologically prior to the question of 'what do I want?' and that agents' identities are in turn governed by the normative

11 Martha Finnemore, National Interest in International Society (New York : Cornell University Press, 1996), p. 63.

${ }^{12}$ Ibid.

13 Ted Hopf, "The Promise of Constructivism in International Relations Theory”, International Security, vol. 23, no. 1 (1998), pp. 172-3.

${ }^{14}$ Jamie Frueh, Political Identity and Social Change: The Remaking of the South African Social Order (New York: State University of New York Press, 2003), pp. 10-1. 
and ideological structures that they inhabit. ${ }^{15}$

Finally, behavior through constructivist eyes is seen as essentially norm-driven, with actor seeking to ensure a correspondence between their own conduct and internalized prescriptions for legitimate behavior that actors have derived from their identities. ${ }^{16}$ On the other hand, behavior defines political identity. The political identities of ulama causes them to support certain candidates.

Mutual action supports the claim that it is best to cast doubt on one of the candidates to encourage voters to change their choice. Excessive action can be seen from some of the scholars who firmly and clearly issued a fatwa against one of the presidential candidates. In one national newspaper, a scholar attacked Joko Widodo saying he should be forbidden from becoming president.

The claims by ulama as to whether the candidates they supported were the best caused skepticism among voters and may have led some to change their choice of candidate. Exaggerated action can be seen from some ulama who firmly issued a fatwa haram against Joko Widodo. As reported in a national newspaper, an ulama even instructed Muslims not to choose Joko Widodo as president. ${ }^{17}$

A reflection of the political identity of the ulama during the presidential election in 2004 is evidenced in their demand for Joko Widodo to establish 1 Muharram as a national santri day if he won. In spite of the demand, there was interest in their attempt to gain symbolic recognition of Islamic involvement since national independence. Nevertheless, the request was aimed at Joko Widodo, and not Prabowo who was financially stronger. This shows that political identity is something constructed not by materialist interests.

\section{Comparing Ulama Behavior in 2014 Presidential Election}

Compared to previous presidential elections, the recent presidential election was the most controversial. Joko Widodo's political career rose quickly, from mayor of Solo, to Jakarta governor, and eventually becoming

15 Ibid.

${ }^{16}$ J.P. Olsen and J.G. March, "The Institutional Dynamics of International Political Order", in International Relations Theory for the Twenty-First Century: An Introduction, ed. by Martin Griffiths (New York: Routledge, 2007), p. 63.

17 "Alasan Forum Ulama Haramkan Memilih Jokowi-JK", Republika Online (6 Jan 2014), http://www.republika.co.id/berita/pemilu/hot-politic/14/07/01/n7zvp7alasan-forum-ulama-haramkan-memilih-jokowijk, accessed 5 Nov 2014. 
president. The other candidate, Prabowo Subianto was no less popular than Joko Widodo. He was formerly known as the leader of the Special Forces Command (Komando Pasukan Khusus; KOMPASUS) in the New Order regime and is former son-in-law of Soeharto.

In the 2004 and 2009 election, political aliran did not run optimally, but in the 2014 presidential election the situation was quite different.

Megawati Soekarnoputri, Amien Rais, and Hamzah Haz were representative politicians in 2004 election, because they were nominated by a party. Amien Rais represented Muhammadiyyah or Muslim scholars, and Hamzah Haz represented the PPP. On the other hand, in the elections in 2004 and 2014, Jusuf Kalla represented first as a businessmen, but in 2009 election he was recommended by Golkar, and was thus deemed a politician.

On assessment, the distribution of Islamist party coalitions shows that not all of the candidates' parties were affiliated with Islamist parties. In the 2004 election, although Hasyim Muzadi was a figure of the PKB, he also represented NU. A shift in the distribution of Islamic party coalitions has just occurred in the 2014 presidential election. In fact, more Islamic parties joined in coalition with Prabowo Subianto than with Joko Widodo.

In the presidential elections of 2004 and 2009, ulama support for the Islamist parties might be assumed as reflecting their political identity, providing a political agenda for the political existence of Islam in Indonesia. In the 2014 presidential election, although only the PKB supported PDIP to support Joko Widodo as president, PKB has massive support from traditional NU voters. PDIP certainly expected greater support from the ulama of NU to influence grassroots voters to choose their candidate. In fact, in the 2014 presidential election, none of Islamist organizations were consistent with their choice. The ulama of both NU and Muhammadiyyah also varied in expressing their political views, for instance, NU did not always support Joko Widodo and Muhammadiyah did not always support Prabowo Subianto.

\section{E. Controversial Fatwa During Election}

The behavior of the ulama during the presidential election was expressed in their statements. Many expressed their acceptance and rejection by issuing controversial fatwa. A fatwa is generally understood as an Islamic legal opinion given by an individual muftī (fatwa-giver) or group of muftīs or ulama at the request of someone, called a mustaft $\overline{1}$ 
(fatwa seeker). ${ }^{18}$ Ulama even issued fatwas to prohibit Muslims from choosing a certain candidate for president or which obligated them to prefer another. This became worrying when ulama made efforts to bias voter choice, which had the potential to trigger social conflict. Ulama justification to both candidates may have been caused by the negative rumors. The fatwas elicited further debate, controversy, and revolved around the question of competency, representation and claims over the silent majority. ${ }^{19}$

A fatwa is reflected in the doctrine of al-amr bi al-ma'rüf wa naby 'an al-munkar (command the good and forbid the evil) which also contributes to this matter (Quran. 3:104). This doctrine is used by ulama to justify their role in politics as they feel that it is their duty to guide and show people what is right and what is wrong in politics, a justification which sometimes conflicts with ethics. ${ }^{20}$

In the 2004 presidential election, several influential ulama of NU, in East Java, issued a fatwa ordering members to vote against any woman candidate for president, and also, in February 2004, an extended plenary meeting or mini tanwir (the second highest assembly) of Muhammadiyah in Yogyakarta also issued a fatwa that supported Amien Rais, a former chairman of the Muhammadiyah, as a presidential candidate. ${ }^{21}$ Fatwas are usually related to civil and religious matters, hence those in the political sphere may trigger resistance among Muslims.

In the national Muslim newspaper, Republika, the Forum of Ummah Ulama Indonesia (Forum Ulama Ummat Indonesia; FUUI) stressed the fatwa haram (forbidding Muslims) to Muslim voters forbidding them to choose Joko Widodo in the 2014 presidential election. They claimed that the pair of candidates (Widodo and Kalla) would provoke potential religious conflict. According to KH. Abdul Kareem, head of Az-Zayyady Boarding School, in Laweyan, Solo, who has known Joko Widodo since he was chairman of the Indonesian Furniture Industry and Handicarft Association (Asosiasi Industri Permebelan dan Kerajinan

18 Mun'im Sirry, "Fatwas and Their Controversy: The Case of the Council of Indonesian Ulama (MUI)", Journal of Southeast Asian Studies, vol. 44, no. 1 (2013), p. 1.

19 Ibid.

20 Arskal Salim and Azyumardi Azra (eds.), Shari' a and Politics in Modern Indonesia (Singapore: Insitute of Southeast Asian Studies, 2003), p. 170.

${ }^{21}$ Ahmad Najib Burhani, "Political 'Fatwa' for Presidential Election is not Legally Binding”, wmw.thejakartapost.com (9 Sep 2014), http:/ /www.thejakartapost.com/ news/2004/06/09/political-039fatwa039-presidential-election-not-legally-binding.html, accessed 11 May 2014. 
Indonesia; ASMINDO) in Solo however, Joko Widodo is a pious and polite person. ${ }^{22}$

\section{F. Endorsement of Joko Widodo or Prabowo Subianto?}

The most critical moment in the election campaign was when many survey results proposed that Prabowo Subianto had won, however the situation changed hastily after Fahri Hamzah, of the Islamist Prosperous Justice Party (Partai Keadilan Sejahtera; PKS) commented that Joko Widodo's agreement to declare 1 Muharram (New Year in the Muslim Calendar) as National Santri Day if he won the election was an insane idea. ${ }^{23}$ Furthermore, it caused controversy and protest among santri and ulama. The reaction triggered many ulama and santri to endorse Joko Widodo and declare themselves anti-PKS.

It shows that the Joko Widodo votes declined in the end of June but he was leading significantly by July 2014. The question is whether there was any relevance between the rise of Joko Widodo's electability and Fahri Hamzah's controversial comment on twitter on 27 June 2014. While it didn't determine the choice of many voters, it did attract reaction from ulama and santri. This sarcastic comment might be the reason why ulama supported Prabowo-Hatta.

The PDIP, which supported Joko Widodo has always been synonymous with abangan and secularism. This has caused the Islamist parties to be reluctant to cooperate with the PDIP. Abangan is often interpreted as the segment of the Muslim community that does not adhere rigidly to Islamic rituals. Instead, the result of a survey of the Muslim community showed that Prabowo Subianto gained more support from Muslim voters $\left(47.30 \%\right.$ ) than Joko Widodo $(46.39 \%) .{ }^{24}$

The doctrine of some ulama who later considered voting for Jokowi as haram, faded away after Fahri Hamzah's controversial comment. The political identity of the ulama may not only be caused by rumors in the media but also their understandings of norms. In accordance with the

${ }^{22}$ Irfan Nuruddin, "Jokowi di Mata Kiai Lokal", www.nu.or.id (30 Jun 2014), http://www.nu.or.id/a,public-m,dinamic-s, detail-ids,4-id,52963-lang,idt,Jokowi+di+Mata+Kiai+Lokal-.phpx, accessed 11 May 2014.

23 Muhammad Muhyddin, "Kubu Jokowi Fahri Hamzah Lukai 37 Juta Santri”, wnm. tempo.co (7 Feb 2014), http://pemilu.tempo.co/read/news/2014/07/02/269589923/ Kubu-Jokowi-Fahri-Hamzah-Lukai-37-Juta-Santri, accessed 10 Oct 2014.

${ }^{24}$ LSI (Lembaga Survei Indonesia), Kebangkitan Seminggu Terakbir Head to Head Jokow-JK vs Prabowo-Hatta, http://lsi.co.id/lsi/wp-content/uploads/2014/07/K OnpersAwal-Juli-2014Kebangkitan-Seminggu-Terakhir.pdf, accessed 10 Oct 2014. 
above themes, the political identities of ulama are constantly changing and are socially constructed in Indonesian political life.

\section{G. Concluding Remarks}

Overall, the political identities of ulama may seem difficult to separate from their interests and political agendas, for example, whether ulama are affiliated to an Islamic party or take a role in politics. On the other hand, ulama involvement in elections is necessary in maintaining neutrality. Unfortunately, some ulama issued fatwas forbidding members to choose certain candidates.

Based on their political identities and evaluation of their behavior in the media, the ulama affiliated in the presidential election misused religion for political purposes. However, the 2014 presidential election may have caused them to reconsider their political attitudes because of the many negative issues that came up during the campaign compared to in the presidential elections in 2004 and 2009. The political identities of ulama are always in a process of change and can contribute in an Indonesian election. Furthermore, safari tradition of politics during the election given its own characteristic to the presidential election in Indonesia. Afterwards, the ulama support appears through a fatwa though if the candidate they have supported did not win the election, the fatwa vanished with the issuing of another. 


\section{BIBLIOGRAPHY}

"Alasan Forum Ulama Haramkan Memilih Jokowi-JK", Republika Online, 1 Jun 2014, http:/ /www.republika.co.id/berita/pemilu/hotpolitic/14/07/01/n7zvp7-alasan-forum-ulama-haramkan-memilihjokowijk, accessed 5 Nov 2014.

Azra, Azyumardi, Indonesia, Islam, and Democracy: Dynamics in a Global Context, Jakarta: Solstice, 2006.

Baswedan, Anies Rasyid, "Political Islam in Indonesia: Present and Future Trajectory”, Asian Survey, vol. 44, no. 5, 2004, pp. 669-90 [http:// dx.doi.org/10.1525/as.2004.44.5.669].

Buehler, Michael, "Islam and Democracy in Indonesia", Insight Turkey, vol. 11, no. 4, 2009, pp. 51-63, accessed 8 May 2015.

Burhani, Ahmad Najib, "Political 'Fatwa' For Presidential Election is Not Legally Binding", The Jakarta Post, 9 Jun 2004, http://www. thejakartapost.com/news/2004/06/09/political-039fatwa039presidential-election-not-legally-binding.html, accessed 11 May 2014.

Croissant, Aurel and Beate Martin (eds.), Between Consolidation and Crisis: Elections and Democracy in Five Nations in Southeast Asia, Berlin: LIT Verlag, 2006.

Finnemore, Martha, National Interests in International Society, New York: Cornell University Press, 1996.

Frueh, Jamie, Political Identity and Social Change: The Remaking of the South African Social Order, Albany: State University of New York Press, 2013.

Hopf, Ted, "The Promise of Constructivism in International Relations Theory", International Security, vol. 23, no. 1, 1998, pp. 171-200 [http://dx.doi.org/10.2307/2539267].

Indonesia Presidential Election Results 2009: An Analysis, 2009, http: / / www.apcoworldwide.com/ content/pdfs / IndonesiaPresidentialElectionResults2009.pdf, accessed 15 Oct 2014.

Kalsum, Umi, “200 Kiai-Habib Dukung Hamzah”, detiknews, 20 Sep 2014, http://news.detik.com/read/2004/05/29/164350/ 159079/10/200-kiai-habib-dukung-hamzah?n992204fksberita, accessed 20 Oct 2014. 
"Kebangkitan Seminggu Terakhir Head to Head Jokow-JK vs PrabowoHatta", LSI; Lingkaran Survei Indonesia, 7 Jul 2014, http://1si.co.id/ 1si/2014/07/07/kebangkitan-seminggu-terakhir-head-to-headjokowi-jk-vs-prabowo-hatta/, accessed 10 Oct 2014.

Kristanto, Ignatius, "Jawa Timur, Tembok Pembatas Mulai Terbelah", Kompas, 22 Jun 2009.

Muhyddin, Muhammad, "Kubu Jokowi Fahri Hamzah Lukai 37 Juta Santri”, Tempo.co, 7 Feb 2014, http://pemilu.tempo.co/read/ news/2014/07/02/269589923/Kubu-Jokowi-Fahri-HamzahLukai-37-Juta-Santri, accessed 10 Oct 2014.

Nuruddin, Irfan, "JK-Win Minta Dukungan Warga Ponpes di Magelang”, kompas.com, 19 May 2009, http://lipsus.kompas.com/ grammyawards/read/2009/05/19/19313579/JK.Win.Minta. Dukungan.Warga.Ponpes.di.Magelangjk2009, accessed 5 Nov 2014.

----, "Jokowi di Mata Kiai Lokal”, www.nu.or.id, 30 Jun 2014, http:// www.nu.or.id/a,public-m, dinamic-s,detail-ids,4-id,52963-lang,idt,Jokowi+di+Mata+Kiai+Lokal-.phpx, accessed 11 Aug 2014.

Olsen, Johan P. and James G. March, "The Institutional Dynamics of International Political Order", in International Relations Theory for the Twenty-First Century: An Introduction, ed. by Martin Griffiths, New York: Routledge, 2007.

Salim, Arskal and Azyumardi Azra, Shari'a and Politics in Modern Indonesia, Singapore: Insitute of Southeast Asian Studies, 2003.

Sirry, Mun'im, "Fatwas and Their Controversy: The Case of the Council of Indonesian Ulama (MUI)", Journal of Southeast Asian Studies, vol. 44, no. 1, 2013, pp. 100-17 [http://dx.doi.org/10.1017/ S0022463412000641].

Slater, Dan, "The Ironies of Instability in Indonesia", Social Analysis, vol. 50, no. 1, 2006, pp. 208-13 [http://dx.doi.org/10.3167/01559770 6780886067 .

The Carter Center 2004 Indonesia Election Report, Atlanta: The Carter Carter, 2005, https://www.cartercenter.org/documents/2161.pdf, accessed 11 May 2014. 